Pensares em Revista, ISSN 2517-2215

\title{
EXPLORATORY PRACTICE AND NEW LITERACY STUDIES: BUILDING EPISTEMOLOGICAL CONNECTIONS
}

\author{
Isabel Cristina Rangel MORAES BEZERRA \\ (Universidade do Estado do Rio de Janeiro) \\ icmoraes@uol.com.br \\ Inés Kayon de MILLER \\ (Pontifícia Universidade Católica do Rio de Janeiro) \\ inesmiller@hotmail.com
}

\begin{abstract}
In this paper, we present Exploratory Practice, a critical-reflexive approach to teaching-learning languages and to research, which focuses on quality of classroom life as its main tenet. We understand that the discussions that have been in progress in the area of literacy studies are also of interest to language teachers and learners as exploratory practitioners. According to Miller (2013) and Moraes Bezerra (2012, 2014, 2015), practitioners' pedagogical work must be directed to the meaning-making possibilities which can empower language users and can contribute to reinventing the social world. We make some theoretical considerations on Exploratory Practice (ALLWRIGHT \& HANKS, 2009; MILLER, 2009), as well as on the New Literacy Studies proposal (GEE, 2000; STREET, 2003, 2005; LEA \& STREET, 2006; STREET, 2009), to help us establish a dialogue between both areas. In order to reflect on this dialogue, we present a teaching-learning experience developed with the help of college students who are in the initial teacher education process of becoming teachers of English as a foreign language.
\end{abstract}

Keywords: Exploratory Practice. New Literacy Studies. Meaning-making possibilities. Quality of classroom life. Initial teacher education.

\section{PRÁTICA EXPLORATÓRIA E NOVOS ESTUDOS DO LETRAMENTO: CONSTRUINDO CONEXÕES EPISTEMOLÓGICAS}

Resumo: Neste artigo apresentamos a Prática Exploratória, uma abordagem para o ensino e aprendizado de línguas, para a pesquisa e para a reflexão, que tem na qualidade de vida em sala de aula de línguas seu princípio maior. Por isso, entendemos que as discussões que têm sido formuladas na área de letramento também são de interesse do professor de línguas, praticante exploratório, posto que seu trabalho pedagógico, segundo Miller (2013) e 
Moraes Bezerra (2012, 2014, 2015), deve estar voltado para formas de construir significados que podem empoderar os usuários da língua, podendo colaborar para a reinvenção do mundo social. Assim, traremos algumas considerações teóricas vindas da Prática Exploratória (ALLWRIGHT \& HANKS, 2009; MILLER, 2009), bem como da proposta dos Novos Estudos do Letramento (GEE, 2000; STREET, 2003, 2005; LEA \& STREET, 2006; STREET, 2009), no sentido de identificar elementos que possam viabilizar um diálogo com a Prática Exploratória. A fim de melhor refletir sobre tal diálogo, traremos uma experiência de ensino e aprendizagem desenvolvida com alunos da universidade, em um curso de licenciatura de inglês como língua estrangeira.

Palavras-chave: Prática Exploratória. Estudos dos Novos Letramentos. Produção de significado. Qualidade de vida em sala de aula. Formação inicial de professores.

\section{A few preliminary words}

In the early nineties, Allwright (in ALLWRIGHT \& BAILEY, 1991, Epilogue) conceived an approach to the language classroom which had a twofold objective: [a] to encourage teachers to become researchers of their own classrooms at the same time as they went on with their teaching; [b] to put quality of life first, regarding the teaching-learning process. At that time, this approach was named Exploratory Teaching and was rather timid about engaging learners in the process. Later, it became known as Exploratory Practice, in order to highlight the proposed integration between an investigative attitude and pedagogic practice. The idea was that it should be possible to rethink teacher research so that teachers (and learners) could use their normal pedagogic activities to search for deeper understandings of their teaching (and learning) lives in language classrooms (ALLWRIGHT, 2003). From that time on, Exploratory Practice has expanded around the world (ALLWRIGHT; HANKS, 2009), but it was clearly in Rio de Janeiro, Brazil, where EP practitioners - both teachers and learners - have become the leading representative voices in Exploratory Practice. We believe that, probably due to local sociocultural factors, Rio de Janeiro teachers and learners from various contexts, when given the opportunity to reflect about what interests them, have focused on the quality of classroom life, i.e., on the interpersonal relations that practitioners create 
within classrooms while teaching and learning are being done. Moreover, learners from socioeconomic deprived contexts naturally have brought to bear the relation that school life has with the macro context of social life and have invited reflection on issues from outside their classrooms or schools. This is why, in times devoted to the role of literacy in societies like ours, and taking into account that the majority of EP practitioners deal with language teaching and learning (English as foreign language, Portuguese as L1) we would like to turn our attention to the connections that we can establish between Exploratory Practice and some discussions on New Literacy Studies. In order to do so, we start by presenting the Exploratory Practice credentials. Then, in this explicit dialogue we make with New Literacy Studies ${ }^{1}$, we develop some considerations on the theory developed by some scholars who have been discussing and doing research in this field. We will be particularly relying upon some concepts and constructs which come especially from Street's discussion. In this attempt, we might miss important issues, or even not tackle the vast knowledge that has been built by New Literacy Studies researchers so far. Nonetheless, we still think it is worth undertaking this task considering the significant contributions that New Literacy Studies and Exploratory Practice have been making to the fields of pedagogy and of research. As the outcomes of a pedagogic philosophy that cares for the other, practitioners' eyes and sensitivity have been oriented to look more deeply into their contexts, not accepting them as given.

\section{1 - Exploratory Practice as a socio-cultural approach to education and to classroom life}

As we are proposing in this text a potentially fruitful dialogue between Exploratory Practice and the New Literacy Studies, we wish to foreground, first, the socio-cultural basis of Exploratory Practice and some of its defining notions.

\footnotetext{
${ }^{1}$ Although Moraes Bezerra (2015) alone already made some links between Street's ideological model of literacy, which will be presented in section 2, and Fairclough's ideas regarding critical literacy in a study in which she described and reflected upon a teaching learning experience that she developed with some learners in a Brazilian school, having the Exploratory Practice framework and principles as support.
} 
1.1 - Classrooms as social events

Very much within the spirit of the 'social turn' movement (GEE, 2000, p.180), we believe that the systematic micro-analytical studies of classroom discourse (ALLWRIGHT, 1988; VAN LIER, 1988, among others) helped specialists in the field of Applied Linguistics accept that, above all, teachers and learners are social beings and that the classroom is a socio-cultural event (ALLWRIGHT, 1996; HOLLIDAY, 1999 ). The vast longitudinal classroom discourse data that were collected ethnographically and analyzed with the support of socio-interactional linguistics or discourse analysis have been showing that, apart from the pedagogical 'content' that was being taught and/or learned, the richest and most fascinating aspects had to do with 'what was going on' among the people in the classroom. Social issues of power, copresence, (a)symmetry, synchronicity, collegiality, among many others, emerged as central to the teaching and learning that were being socio-culturally co-constructed in classroom discourse (CAZDEN, 1988; ERICKSON, 1996).

With such empirical evidence as backdrop, Exploratory Practice was born out of Allwright's (1998) precious understanding that teachers and learners coconstruct classroom life building upon their understandings of the social, cultural and interpersonal dimensions that are negotiated in classrooms. So, aligned with Allwright (ibid.) and with Gee (2000, p. 184), we believe that in classrooms, just as in other social contexts, "knowledge and meaning are seen as emerging from social practices or activities". Within Exploratory Practice, classrooms are conceived as locales in which learning opportunities (ALLWRIGHT, 1995) emerge all the time. As research has shown the importance of learners as managers of their own learning opportunities (SLIMANI, 1987), Allwright unsettles the field of Applied Linguistics by stating that learning cannot be planned for. Strongly acknowledging the "essential idiosyncrasy of humanity", Allwright (2006, p. 13-14) suggests that the best we can do as teachers is to adopt "a scattergun approach, whereby you offer a multitude of learning opportunities for learners, and expect them to select according to their own particular needs". 


\section{2 - Work for understanding}

Apart from aligning itself with such an autonomy-oriented conception of learning, the framework of Exploratory Practice (ALLWRIGHT, 1991, 2003; MILLER, 2001; MORAES BEZERRA, 2007, 2011; ALLWRIGHT \& HANKS, 2009; among many others) also presupposes that teachers and learners can 'work for understanding' what interests them about what goes on in their classrooms. Most importantly, they can do so as part of their daily pedagogic routine, in order to turn this work sustainable. As we find in Allwright \& Hanks (2009, p. 149-161), in the past two decades or so, exploratory teachers and learners, have enacted Principle 2 whenever they "work primarily to understand" their relevant puzzles, generally formulated as 'why' questions. Also, exploratory practitioners perform Principle 7, according to which "integrating the work for understanding into their existing curricular practices is a way of minimizing the burden and maximizing sustainability". Such integration leads teachers to create and engage in Potentially Exploitable Pedagogic Activities (ALLWRIGHT, 2006; BARRETO et al, forthcoming, among many others), which offer language learning opportunities as well as opportunities for the development of reflexivity about the puzzles in question. In so doing, exploratory classroom practitioners have not only reorganized their pedagogy as 'puzzle-driven' work (MILLER, 2009), but have also reinvented social life in the classroom (MOITA LOPES, 2006; MILLER, 2013). This internal organization around relevant classroom puzzles or life-world issues echoes what happens among members of communities of practice (WENGER, 1998; GEE, 2000). In section 4, we illustrate these processes by drawing on examples of Exploratory Practice work developed specifically in initial teacher education university courses.

\section{$1.3-$ Collegiality and agency}

The ethos that is coconstructed in and through Exploratory Practice work is inextricably associated to the notions of collegiality and agency. Teachers 
and learners (or practitioners in other contexts) can work collectively and collegially for mutual development; the ethical core of Exploratory Practice, thus, being systematized by Allwright \& Hanks (2009, p. 151) as follows:

Principle 3: Everybody needs to be involved in the work for understanding.

Principle 4: The work needs to serve to bring people together.

Principle 5: The work needs to be conducted in a spirit of mutual development.

As we shall see in section 4 of this paper, "work for understanding" in order to "bring people together" is motivated by a genuine belief in the possibility of "mutual development". As Allwright \& Hanks (2009, p. 151) clarify,

If anyone needs to understand, then everyone needs to understand (especially if we see situational understanding as the collective property of the group, rather than of each individual separately). [Italics ours]

This is why exploratory practitioners as authors of texts in both English and Portuguese, have been emphasizing the plurality of 'understandings' (ALLWRIGHT \& HANKS, 2009; EWALD, 2015; MILLER, et al, 2015; SANTOS, 2015; MORAES BEZERRA, 2015, among others). This discursive decision attempts to reinforce the exploratory practitioners' agencies, which presuppose the view of learners that Allwright \& Hanks (2009, p. 7) express in the Five Learner Propositions, slightly paraphrased as follows: Learners are unique individuals who learn and develop best in their idiosyncratic ways, in a mutually supportive environment. They are capable of taking learning seriously, of independent decision-making and of developing as practitioners of learning.

It is interesting to mention that, during his visits to Rio de Janeiro, Allwright discussed preliminary versions of these propositions with teachers and learners in the 2006 Annual Exploratory Practice Event organized by the Rio EP Group. These sessions were considered by group members as collegial 'work for understanding', whereby Allwright refined his formulation of this set of statements about a refreshingly promising view of learners. Recently, a newcomer to the ideas of Exploratory Practice shared, with pleasure, her sudden understanding that these propositions could also characterize teachers as learners, thus reinforcing Allwright \& Hanks' view of both teachers and learners as developing practitioners of learning. 
Having briefly sketched the central notions that characterize Exploratory Practice, we now turn to a selective presentation of the area of New Literacy Studies. As we mentioned earlier, the intention is to explore potentially fruitful connections between both sets of practices.

\section{2 - New Literacy Studies: identifying some issues for an initial dialogue}

In the realm of New Literacy Studies (BARTON, HAMILTON, IVANIC, 2000; STREET, 1995, 1998, 2003; GEE, 2000) one of the core issues is related to the complexity of literacies - or multiple literacies - as literacy is conceived as a socially, historically and culturally situated practice. Therefore, literacy must not be viewed as a unique issue, but as the multiple ways in which reading, writing, and meaning making are done in different social settings with diverse purposes. Thus, according to Gee (2000, p.189) "reading, writing and meaning are always situated within specific social practices, within specific Discourses".

Also according to Gee (n.d.), New Literacy Studies brought an opposing psychological approach to literacy in traditional psychology which viewed it as a cognitive phenomenon, involving mental states and mental processing alone. New Literacy Studies, however, brought to scene another way of viewing $i^{2}$ :

The NLS saw literacy as something people did not just do inside their heads but inside society. It argued that literacy was not primarily a mental phenomenon, but, rather, a sociocultural one. Literacy was a social and cultural achievementit was about ways of participating in social and cultural groups-not just a mental achievement. Thus, literacy needed to be understood and studied in its full range of contexts-not just cognitive-but social, cultural, historical, and institutional, as well. (GEE, n. d., 2)

Accordingly, in everyday social practices, people do things with texts that involve more than just reading and writing. It involves other people in various contexts. Therefore, to NLS researchers, what determines how a person reads or writes is not only a cognitive matter. In fact, it encompasses "the conventions, norms, values, and practices of different social and cultural groups" (GEE, n.d.,

\footnotetext{
${ }^{2}$ In fact, this is very much aligned to Vygotsky's sociocultural approach that accounts for how humans learn and how the learning process that is historically, socially, and culturally situated influences the construction of the structures of higher mental functions. The author claims that the mind is socially constructed.
} 
p. 2). Also, reading and writing are articulated to oral language and to action, to different ways of knowing, valuing, believing as well as to ways of using tools and various technologies.

Hamilton (2010, p. 7), problematizing on teaching adult literacy, mentions the traditions of literacy teaching that view it as "a discrete set of skills that can be acquired step by step". These skills ${ }^{3}$ are encompassed by the expression "basic literacy". Although she recognizes that foundation skills are important, literacy goes beyond them. While making a link with teacher practice, Hamilton claims that teachers need to understand "how skills are shaped by the social contexts, purposes and relationships within which reading and writing are used" (ibid.). Therefore, the limited view of literacy encountered in those teaching traditions can be linked to the autonomous model of literacy proposed by Street.

In order to characterize the new approaches to understanding and defining literacy so as to discuss the ways through which literacy has been viewed in research and in educational policy, Street $(1995,2003,2005,2012$, n. d.) made a distinction between the autonomous model and the ideological model of literacy. According to him,

[the first model] works from the assumption that literacy in itself - autonomously will have effects on other social and cognitive practices. It is assumed that the acquisition of literacy will in itself lead to, for example, higher cognitive skills, improved economic performance, grater equality, and so on. It is in this sense that literacy is seen as having such effects "autonomously", irrespective of the social conditions and cultural interpretations of literacy associated with programmes and educational sites for its dissemination. The model, however, disguises the cultural and ideological assumptions that underpin it and that can then be presented as though they are neutral and universal. (STREET, 2005, p. 417)

Hence, we could point that a corollary to this view of literacy is the understanding that there is only one way of doing literacy which is the one privileged by schooled education. Besides, the individual learner is the sole responsible for failing or succeeding in literacy practices associated to formal education. In opposition to this model, the ideological model of literacy has a more culture oriented and sensitive view to social practices of which literacy is a

\footnotetext{
${ }^{3}$ Some of these skills, Hamilton (2010) explains, are foundation ones, such as spelling accurately, and forming letters through handwriting. This author mentions that more complex linguistic and information skills are also involved.
} 
part of, since in New Literacy Studies it is assumed that literacy practices vary from one context to another. According to this model,

literacy is a social practice, not simply a technical and neutral skill, that it is always embedded in socially constructed epistemological principles. It is about knowledge: the ways in which people address reading and writing are themselves rooted in conceptions of knowledge, identity, being. Literacy, in this sense, is always contested, both its meanings and its practices, hence particular versions of it are always "ideological"; that is, they are always rooted in a particular worldview and a desire for that view of literacy to dominate and to marginalize others. (STREET, 2005, p. 418)

In this sense, other ways of doing literacy in literacy events in everyday life started to be identified through research. That is, the possibility of acknowledging other ways of using reading and writing apart from the scope of schooled practices and which are integrated to how people carry on their lives, sell and buy products, fight for their rights, contest or align themselves to worldviews, and so on. Obviously, this is linked to the set of assumptions, ideas, beliefs, knowledge and so on that people take with them to literacy events, and particularly that learners bring to school and which are present in different classes of different subjects. This brings to scene issues related to power relationship. In fact, Street (2005) calls attention to the fact that the ideological model of literacy is named ideological because, beyond emphasizing the cultural meanings, it also emphasizes the power dimensions of reading and writing processes. This might entail looking at the local - that is, how the group that 'receives' or 'is imposed' a literacy practice which is not produced/devised by their own participants, react to this process, how they take the ideas and concepts from this distant group from whom the distant literacies come.

At this point, it is interesting to present some criticism brought about by Brandt and Clinton (2002), and mentioned by Street (2003) himself. Those authors claim that New Literacy Studies might be exaggerating the power of local contexts and that literacy practices are not produced or created by the practitioners that are using literacy in their daily social practices. Those literacy practices, they add, are not independently chosen or sustained by those practitioners since literacy serves multiple interests and incorporates "individual agents and their locales into larger enterprises that play out away from the immediate scene" (BRANDT; CLINTON, 2002, p. 1 as cited in STREET, 2003). 
This includes the understanding that literacy comes from outside; therefore, it brings with it skills and meanings that are larger than the emic perspective favored by New Literacy Studies. In spite of acknowledging that it is necessary to be careful not to overemphasize the local, Street claims that distant literacies are also ideological as any literacy practice is. He also makes a point that it is necessary to devise a framework as well as conceptual tools in order to characterize the relation between local and distant. Nonetheless, that was a question

[...] raised in the early NLS work concerning how we can characterize the shift from observing literacy events to conceptualizing literacy practices does, I think, provide both a methodological and empirical way of dealing with this relation and thereby taking account of Brandt and Clinton's concern with the "limits of the local" (STREET, 2003, p 80 ).

At those early stages, according to Street (2003), to use the term 'literacy' as a unit or object of study would be a problem for researchers doing ethnographic studies who were using the ideological model of literacy as a reference, since the term 'literacy' is already loaded with ideological and policy presuppositions. So, two constructs were developed in the area and researchers started using them: literacy practice - that is, "the broader cultural conception of particular ways of thinking about and doing reading and writing in cultural contexts" (STREET, 2003, p. 79) - and literacy event - that is related to "any occasion in which a piece of writing is integral to the nature of participants' interactions and their interpretative processes" (HEATH, 1982, p. 371).

Still discussing Brandt and Clinton's remark, Street (2003, p.80) argues that "NLS practitioners might take issue with the apparent suggestion that distant literacies come to local contexts with their force and meaning intact". Commenting on a study made by Kulick and Stroud (1993), Street (ibid.) calls attention to the fact that what results from local-global encounters regarding literacy is not an essentialized version of either literacy practice, but hybrid ones. And these are the concern of New Literacy Studies.

Bearing in mind the implications that this approach to literacy has to research, with many studies and publications drawing upon "ethnographic perspectives to describe literacy practices across different cultural contexts" (STREET, 2012, p. 6), the outcomes of research have contributed not only to academic research itself, that is, to broadening the scope of the studies, and to 
drawing the researchers attention to literacy practices in a great variety of contexts. They also contributed to the building of an epistemological niche. Obviously, these studies can also influence practice and policy as Street emphasizes. In a 2005 text, Street expresses his concern on how the New Literacy Studies framework could be relevant to the work of teachers in and out of school. That means that New Literacy Studies should not only account for literacy practices, but, by the same token, provide relevant insights for those directly involved with literacy as New Literacy Studies were applied in educational contexts. Thus, it seems that New Literacy Studies started in the academy with researchers pursuing their own agenda, and, then, made a move towards meeting the demands of teachers and students. Back in 2003, Street had already pointed that it would be required of New Literacy Studies to "move beyond these theoretical critiques and to develop positive proposals for interventions in teaching, curriculum, measurement criteria, and teacher education in both the formal and informal sectors" (STREET, 2003, p.82). In this article, the author shows his concern towards recognizing, valuing, and using "the understandings of children's emerging experiences with literacy in their own cultural milieus to address broader educational questions about learning of literacy and of switching literacy practices required in different contexts" (ibid, 83).

Again, in 2005, Street voiced his concern regarding the relation between New Literacy Studies and school literacy practices, if we can say so. In this article, Street mentioned one of his recent books in which the reader could find "case studies of innovative educational projects by researchers and practitioners working across the boundaries of traditional educational institutions and the everyday lives of their students" (ibid.p.422). He even revisited a checklist of features of New Literacy Studies that he had proposed before (STREET, 1997) and which were already well established in theory. However, in what comes to the application of such features to practice, careful work would be necessary. The features that Street had in mind were the following:

1. Literacy is more complex than current curricula and assessments allow.

2. Curricula and assessments that reduce literacy to a few simple and mechanistic skills fail to do justice to the richness and complexity of actual literacy practices in people's lives. 
3. If we want learners to develop and enhance the richness and complexity of literacy practices evident in society at large, then we need curricula and assessments that are themselves rich and complex and based upon research into actual literacy practices.

4. In order to develop rich and complex curricula and assessment for literacy, we need models of literacy and of pedagogy that capture the richness and complexity of actual literacy practices.

5. In order to build upon the richness and complexity of learner's prior knowledge, we need to treat "home background" not as deficit but as affecting deep levels of identity and epistemology, and thereby the stance that learners take with respect to the "new" literacy practices of the educational setting.

Taking the above checklist, we would like to highlight the clear concern for learner's previous knowledge, for the richness and complexity of curricula and assessments of literacy - when literacy is considered as a complex issue itself, for acknowledging that "home background" does affect identity, epistemology, as well as the learners' attitude towards the literacy practices faced at school.

New Literacy Studies also influenced student writing in higher education in an English as L1 situation (or even in an ESL/EFL situation). This issue was addressed because it was claimed that the students could no longer write (LEA; STREET, 1998). Moving away from this idea, Lea and Street viewed learning in higher education as an adaptive process to new ways of knowing, as well as of understanding, interpreting and organizing knowledge. In the academic scenario, there are different academic literacy practices, that is, reading and writing within disciplines. According to these writers, these practices "constitute central processes through which students learn new subjects and develop their knowledge about new areas of study" (LEA; STREET, 1998, paragraph 3).

Both authors (1997), based on educational research into student learning in higher education, identified three approaches to characterize academic literacy which influence actual academic literacy practices or, in other words, practices that academic staff or faculty members draw upon to plan classes, write reports, prepare and ask for academic tasks. They named these models as follows, according to Street (2010, p. 347-349):

[a] Study skills approach - "literacy is a set of atomized skills which students have to learn and which are then transferable to other contexts. The focus is on attempts to 'fix' problems with student learning, which are treated as a kind of pathology. The theory of language on which it is based emphasizes surface features, grammar and spelling. Its sources lies in behavioral 
psychology and training programs and it conceptualizes student writing as technical and instrumental" (2010, p. 347).

[b] Academic socialization approach - "the task of the tutor/advisor is to inculcate students into a new 'culture', that of the academy. The focus is on student orientation to learning and interpretation of learning tasks. Through conceptualization, for instance of a distinction between 'deep' and 'surface' learning [...] The sources of this perspective lie in social psychology, in anthropology; and in constructivist education".

In spite of acknowledging that this approach is more sensitive to the learner and to the cultural context, Street offers some criticism to it. To him, it "appears to assume that the academy is a relatively homogeneous culture" (STREET, 2010, p. 348), and once its norms and practices are learnt they provide access to the whole institution. Street also criticizes this approach for not theorizing on the exercise of power in institutional practices. Finally, he states how writing is treated "as a transparent medium of representation and so fails to address the deep language, literacy and discourse issues involved in the institutional production and representation of meaning" (ibid.).

[c] Academic literacies approach - which is the "most closely allied to the New Literacy Studies". [...] It "sees literacy as social practices", [...] and "views student writing and learning as issues at the level of epistemology and identities rather than skill or socialization. [...] it "views the institution in which academic practices take place as constituted in, and as sites of, discourse and power. It sees the literacy demands of the curriculum as involving a variety of communicative practices, including genres, fields and disciplines. From the student point of view, a dominant feature of academic literacy practices is the requirement to switch practices between one setting to another, to deploy a repertoire of linguistic practices appropriately to each setting, and to handle the social meanings and identities that each evokes. This emphasis on identities and social meanings draws attention to deep affective and ideological conflicts in such switching and use of the linguistic repertoire" (2010, p. 349).

After this long retrieval and discussion of so many aspects regarding New Literacy Studies, as language teachers and teacher educators aligned with Exploratory Practice, we asked ourselves how these issues are considered in our institutions and in our classrooms. Thus, we turned our attention into 
thinking how they are present in the academic daily practices that we develop with our students, particularly regarding the Exploratory Practice attitude to teaching and learning. By the same token, those aspects made us think on what Exploratory Practice can or has to say regarding power and learners' written production. Obviously, these are not easy or simple issues to be addressed. One of the reasons for this is that we can only talk about practices we are involved with, let alone what other exploratory practitioners say or do regarding the aspects we presented. Hence, in the next section we try to describe, analyze and reflect on a specific moment in which some first-year students, two undergraduate teaching-assistants and a teacher were involved in some 'work for understanding'.

\section{3 - At college: experiencing a reflexive process guided by the Exploratory Practice principles in a teacher education program}

Before presenting the Exploratory Practice teacher education experience that we wish to connect with New Literacy Studies, it becomes relevant to explain that, in the past twenty-five years, Exploratory Practice has expanded in various directions in the context of Rio de Janeiro. As mentioned earlier, the seminal ideas were systematized in the context of a large private English language teaching course and focused on the professional development of its large body of experienced teachers. In 2008, Miller et al. explain how Exploratory Practice had already flourished in university-level initial teacher education courses, in public and private schools and in academic research carried out as part of post-graduate degrees.

With Allwright's (2008) speculative support given to the 'novel' initiative of implementing Exploratory Practice in initial teacher education, as an alternative approach to technicism, considerable challenges continued to be met and discussed over the past fifteen years by several members of the Exploratory Practice Rio Group (MILLER, 2009, 2010, 2013; MILLER et al., 2009; MORAES BEZERRA, 2011, 2014; BARRETO et al, forthcoming). The difficulties faced by some EP teacher educators have been critically acknowledged and reflected upon on several occasions. We find them summarized in Allwright and Miller (2012, p. 110): 
Introducing EP into the Teaching Practice course highlights tensions between learnerteachers' previous school-education, traditionally built upon compartmentalized knowledge-making, and the sharing, interdisciplinary, co-constructed pedagogic practice we propose. We notice an underlying discomfort when our questioning and reflective posture meets our learner-teachers' desire for clear and precise instruction from others. We willingly face this dilemma of creating such pre-professional stress, hoping thereby to foster opportunities for enhancing self-knowledge and strengthening self-esteem. As teacher educators, this is our biggest challenge. It is also our most hopeful investment: fortifying future teachers against the pressures of school life that threaten eventual burnout.

Despite the challenges associated with encouraging practitioners teacher learners and teacher educators - to 'work for understanding' the puzzling issues that emerge in their daily lives in and out of classrooms, investing in Exploratory Practice with future teachers has helped us emphasize ethical aspects of inclusivity and its focus on 'quality of life'. In this realm, the prioritization of the latter is of utmost importance. But what does 'quality of life' mean to EP practitioners? In its life oriented approach, Exploratory Practice cares for and is interested in the 'nature of life in the classroom', its complexity as well as in the "multifaceted interpretative processes based on frameworks of interpretation of expectations of what constitutes a good or a poor quality of classroom experience" according to practitioners (GIEVE \& MILLER, 2006, p. 20).

This means that Exploratory Practice, in its pedagogical orientation, is not concerned with success regarding a technical practice that seeks for results that can be measured. In relation to research, Exploratory Practice is not concerned with generalizable outcomes, but with understandings that might encourage and nurture a reflexive and inclusive attitude, an ongoing desire to pose new questionings regarding what goes on in and out of the language classroom and that is present or integrated with the literacy practices that are under way. Allwright and Hanks (2009) state that "EP is primarily about understanding, not change"; however, they add the idea below after linking Exploratory Practice to Kenny and Savage's (1997) characterization of a sustainable development work:

Claiming now that it [EP] is nevertheless 'change-oriented' requires some justification. EP's attitude to change is complex. We certainly oppose change for change's sake, and argue instead that by prioritizing understanding over change, EP becomes, as we have seen, an agent for profound and lasting change. (ALLWRIGHT; HANKS, 2009, p. 259) 
Therefore, instead of seeking for solutions which many times are not available or are hastily pursued, once one considers the intricacies, fragmentation and complexity of life, Exploratory Practice encourages each practitioner to 'work to understand' the context of their practices and the practices themselves, the interpersonal relations that are built among them, or any issue that puzzles them. Obviously, the resulting understandings might provoke changes (see the quotation above), even though they cannot be easily or clearly detected sometimes, given the fact that they may be subtle in nature, requiring the practitioner to take a different stance or even look differently at the issue that provoked the puzzlement in the first place. After all, what actually matters to exploratory practitioners is to engage in a process of mutual development so that everyone gains or builds understandings out of the collaborative reflexive process that is socially and culturally situated. In the reflective or institutional context (whether located in a classroom; in the teacher's lounge; in a room where a teaching assistant works or where an educational supervisor or a language consultant works with a group of teachers), language plays an important role. Its use involves Discourse and discourses - in Gee's (2000) terms -, different genres ${ }^{4}$ (BAKHTIN, [1992]2000), as well as the broader socio-historical context.

In order to conduct the reflexive process, either integrated into classroom practices or into research, exploratory practitioners usually use the Exploratory Practice principles to frame their actions. This means that these principles function as guidelines and help practitioners to devise the language class and/or the research design. Another important construct to that process are the so called Potentially Exploitable Pedagogic Activities (PEPAs) - slightly adapted pedagogic activities that teachers and learners are familiar with. They are used as tools to involve practitioners in the reflexive process at the same time that teaching-learning and/or research is going on. A classic example is Santiago's (2006, p. 17) activity related to 'quality of life' in one of her own English as a foreign language classes in a public school in Rio de Janeiro. In order to understand her puzzle, "Why am I so irritated with my 807 class?", the teacher asked her learners to write a few sentences using 'should 'or 'must' (the

\footnotetext{
${ }^{4}$ It should also be taken into account how Street and Lea $(1998,2006)$ somehow broaden this concept.
} 
language point they needed to address according to the syllabus) to describe the teacher's and the learners' roles. Santiago collected the sentences and grouped them at home. She took them to class on the next day and elicited comments about their life in common and their future as a group. Santiago and her group reached many understandings especially about responsibility for their actions. She ends her narrative saying "Now we are really a group! Our life in class is much better!"

Having brought these considerations on Exploratory Practice as a reminder of the issues we mentioned in section 1, it is time to share the teaching-learning experience that Moraes Bezerra had with a group of preservice teachers (also first-year students) at a university-based Teacher Education College ${ }^{5}$ during the English I classes. Besides these first-year students and the teacher (Isabel), other pre-service teachers were involved. These were Diego and Kleber, two undergraduate teacher assistants participating in the English I Teaching Assistantship Project coordinated by Isabel. Prior to actually developing activities with their colleagues of English I class, the teacher assistants had some meetings with Isabel in order to talk about the directions that could be established not only to the English classes given by Isabel, but also to the activities developed by the teacher assistants to their colleagues. Thus, under Isabel's surveillance, they planned activities, produced material, and implemented them.

At this point, and before we go further with this narrative of their joint experience, it is important to share that both Diego and Kleber had already taken three courses - English Language Teaching Methodology, Foundations and English Language Teaching Practice I and $\mathrm{II}^{6}$ - all of them taught by Isabel. In each of these courses, the content that had to be covered by Isabel and mastered by the learners was deeply reflected on. As a result, the group - preservice teachers and teacher - engaged in a process of reflecting on the beliefs and previous knowledge they had regarding the teaching of English as a foreign language in Brazil. Diego and Kleber, as well as their classmates, were encouraged to use the puzzles that emerged from their lives - as students, as

\footnotetext{
${ }^{5}$ Faculdade de Formação de Professores, UERJ.

${ }^{6}$ Metodologia do Ensino de Inglês, Fundamentos e Prática de Ensino de Língua Inglesa I e II.
} 
teachers-to-be, as citizens, ultimately, as human beings - to frame the lesson plan upon them.

This Exploratory Practice ethos was also an integral part of the planning of reading, listening, writing, speaking, and grammar activities of the English I course. Therefore, when Diego and Kleber started the teaching assistant activities, they were already accustomed to bringing to light relevant issues of the social world that affected the quality of life in the language classroom (and the quality of their personal lives in and out of the classroom). Below, we add a fragment from Kleber's reflexive journal. By doing so, we intend to "feel" how he viewed their task and, later, establish a link with one of the activities they planned. Hence, according to his perception:

Our activities in class, as the name suggests, include all sorts of the support that the so called "freshmen students" may need or may require, given that this is their first experience with the English language within the college. I believe that is our role to try to make the students feel as comfortable as possible in the classes, reaching out their doubts in a way that maybe they do not feel so secure speaking up loud during the classroom. As an introvert person, I know how important is to have a relaxed and "safe" environment where it is possible to talk more freely with someone that you feel comfortable with, scenario that can get more relevant if we take in consideration the incourse-process of adaptation to college and all the demands that they will have to deal with, from now on. (Excerpt 1 - Kleber's journal) ${ }^{7}$

From this excerpt, we highlight his concern with the freshmen's feelings ("that is our role to try to make the students feel as comfortable as possible in the classes"), with catering for their learning needs regarding the English classes they were attending at college. We also call attention to the fact that this concern, as was voiced by Kleber ("reaching out their doubts in a way that maybe they do not feel so secure speaking up loud during the classroom"), derived from his own experience in college ("As an introvert person, I know how important is to have a relaxed and "safe" environment where it is possible to talk more freely with someone that you feel comfortable with"). It was not a result of applying any theory about learning; although, we can say he was somehow theorizing out of his experience as a learner. Regarding the process of planning itself, Kleber includes it as one of the teacher assistants' tasks, as can be seen in excerpt 2.

\footnotetext{
${ }^{7}$ In this study, we have maintained the original text produced by the students in the excerpts, quotations and posters analyzed.
} 
Going further, class planning was among the activities we had to develop as part of the teaching assistantship, having in mind that the planned class content had to have some connections with subjects in class, but not necessarily restrict to it, with the objective to help them perceive things in a comprehensive manner. Starting from this point and having the Exploratory class guidelines as our base, we started to reckon and discuss about themes that would provoke some debate and possible puzzles to work in the classroom. (Excerpt 2 - Kleber's journal)

Therefore, Kleber's words evidence the need to integrate the discussion about language, as it is expected in English as foreign language classes, to the real use of language that people make in different texts of different genres in a variety of social contexts. These texts carry people's beliefs, opinions, political positions, and so on. They may be the basis for different literacy events and conform to different literacies - whether or not acknowledged by formal schooling. These very texts circulate in the social world, somehow influencing other people and their actions. We want to pick the expression "Exploratory classes guidelines" from the above excerpt since it seems to point to the understanding of Exploratory Practice as an approach to classroom practice. We interpret Kleber to be probably thinking of the Exploratory Practice principles as the guidelines that can help practitioners to structure class design. By framing the class with this 'exploratory attitude' towards language and life, the teaching assistants paved the way for the emergence of puzzles of different sorts.

The 2015.1 English 1 class was formed by a total of thirty-two young men and women ${ }^{8}$. Some of them dropped out and, by the time that Diego and Kleber implemented the activity, there were twenty-eight first-year students attending classes. Obviously, the desire to major in Modern Languages (Portuguese and English) and Literature was one of the linking elements for that group. In addition, most of them did want to become teachers. For instance, Breno had given up a History course at college, which was part of his professional dreams. In his autobiography ${ }^{9}$ he explained why he had decided to become a teacher of

\footnotetext{
${ }^{8}$ In fact their ages ranged from 17 to 30 .

${ }^{9}$ English I classes were also a site for reflecting on career choice. Therefore, parallel to teaching English through a genre approach, Isabel involved these pre-service teachers in their first semester at college to think about what had made them decide to become teachers. By doing so, they might unearth beliefs, assumptions, and narratives which could foster understandings about what becoming a teacher meant to them and the efforts they were willing to make in order to become one. This was done on several opportunities. One of them happened when the group discussed the function of [auto] biographies in daily life and these
} 
English: "[...] because since the day that I started to learn English I really liked it and I felt so good that I wanted to try to do the other persons feel the way I did". Likewise, Weller shared his feelings for being at college: "In 2015, [...] I was approved to study Letras Inglês at UERJ-FFP, where I study currently. I'm on my first semester of college, and I'm so happy because I revived this dream, and now I feel like I'm living a dream. I love my college and my future profession. I intend to work as an English teacher soon". Although some learners at English I were a bit shy, this was a cheerful group of students. Despite the fact that the majority of students had some previous intermediate knowledge of English [as a foreign language], they needed to improve their oral and written comprehension skills, as well as their productive ones. This means that, in order to pursue the university course, they would have to develop academic literacies, as claimed by Lea and Street (1998).

3.1 Teaching assistants, English I students and a Potentially Exploitable Pedagogic Activity (PEPA)

The focus of our discussion regarding Exploratory Practice and New Literacy Studies will make us now turn our attention to one activity that was planned by Diego and Kleber, but was implemented during the English I class itself, with Isabel's help. Both teaching assistants decided to prepare a lesson to focus on a recent issue that had called people's attention in Brazil. In Diego's words:

\footnotetext{
My choice for picking the theme of racism was motivated by a horrible case of racism that took place in Brasília and reverbed through the internet: a black model that was insulted just because she posted on her Facebook page some pictures of herself. The most disgusting part of these incredible racist comments (it was very hard to rank what was the most disgusting part between them) regarded the comments which seemed to state that she could not be considered beautiful just because of her race. This entire situation was very distressing for me. Thus, the choice of this theme was also a good opportunity to vent out all my anger about this event. (Excerpt 3 - Diego's journal)
}

His personal standpoint is clearly stated regarding his choice. If we pay attention to word selection- i.e. "distressing, disgusting, vent out my anger" - it is possible to grasp how touched he was by that fact. Kleber, likewise, stated

pre-service teachers were encouraged to write their own as part of a dynamic reflexive process articulated to academic activities in that subject. 
his standpoint regarding the racial issue and the decision to choose such a theme.

It is possible to say that one of the first subjects that we thought of was indeed racial prejudice against African-American people, given that at that time, one terrible occurrence of this topic was really recent: a black Brazilian girl was being heavily hostilized with insults concerning her skin color, only due to the reason that she was dating a white boy. Apparently, for those aggressors, this relationship between those two was something unacceptable, fact that is a huge absurd if we consider the origins of our country and empathy towards another human being.

I also felt that the subject spoke to me directly, since I identify myself as a young black man and was eager to hear and understand what my college mates were thinking of this whole situation that is not simply a bunch of isolated cases, but a wider scenario that sadly, is engraved within the roots our society. (Excerpt 4 - Kleber's journal)

In the above excerpt, it is possible to notice that besides voicing how that situation related to him personally ["I also felt that the subject spoke to me directly, since I identify myself as a young black man"], Kleber was also willing to involve his colleagues in a reflexive process ["and was eager to hear and understand what my college mates were thinking of this whole situation"]. This attitude clearly shows that he was trying to put into practice one of Exploratory Practice's principles, namely, "Everybody needs to be involved in the work for understanding" (ALLWRIGHT \& HANKS, 2009, p. 151). Besides, this action would imply collaborative work out of which each practitioner would produce his or her own understandings through his/her discourse actions. And this would be achieved by implementing the PEPA.

In order to go on with class planning, both had to discuss and decide what to do. Excerpt 5 brings some reflection on this moment. Diego reasserts what they intended to reach with the topic that they had chosen, the language skills they would like to help English I learners to develop:

By the time Kleber and I were discussing about the way we would structure our class, we considered a lot all the reflections and debates we had during our meetings with Isabel. We tried to prepare a class in which the students would have the opportunity to enhance their communicative skills, especially regarding their ability of having conversations in English. However, Kleber and I did not want this class to be only like a conversation class in which the topic is chosen randomly. Instead, our main objective was to foment a thorough reflection about the subject covered. (Excerpt 5 - Diego's journal).

Looking more closely at the description of the development of the activity procedures in excerpt 6 , it can be seen that Diego and Kleber chose oral and written texts on which to base the linguistic reflection. These texts would also 
serve as the basis for the critical reading (BRASIL, 1998, 2008) that they would encourage their colleagues to do.

The first part of the activity, the reading of the four pieces of news regarding the theme of
racism, aimed at stimulating all the students to talk among themselves. First, they would
have to debate in their own groups about their specific piece of news in order to find out
what would be the topic of it. Secondly, they would have exchanged this information with
all the other groups. Therefore, the students would be stimulated to mingle with others in
order to put together the pieces of the puzzle. By the end of the information exchange,
they should be able to see clearly that all the pieces of news talked about racial prejudice
in different contexts.
After this first activity, an excerpt of an episode of the "Fresh Prince"10 was presented.
Kleber and I thought that this listening activity could be a good opportunity to present a
different and less privileged variety of English: African-American English. The video
would also foment an open debate about the theme of racial prejudice, thus linking this
issue, presented in the video through the perspective of the American context, to the
reality we face in Rio de Janeiro. In this debate, the students could relate their personal
experiences with the theme as well as their opinions and reflections. (Excerpt 6 - Diego's
journal)

The way the class was planned allowed English I students to read the texts, engage in a reading comprehension activity and share not only their opinions, but, chiefly, some personal narratives involving racist episodes inside and outside college campus. It was possible to feel their sadness, anguish, and shame. To some of them, it was like being able to air sad feelings that they had been hiding. Although they tried to stick to English, there were some moments in which they switched to Portuguese because they felt that they were not proficient enough in English to put into words how they felt. At those moments, neither the teacher, nor the teacher assistants prevented them from doing so. This was also noticed by Diego and Kleber and can be traced in excerpts 7 and 8 below.

I particularly can say that it was a great moment in class for me, the professor and for them, too. They brought up questions and reflections linked to theme straight from their personal lives, things that were real and that I felt that, in some students' approach, they had the urge to talk about it. They were using the English language not only to learn things such as grammar, that is also important, but were making use of the language to create a closer link to it. The students were making use of the language to create,

10 The texts used were the following: "Town elects black female mayor, officials quit" (Retrieved from: http://www.newser.com/story/205710/town-elects-black-female-mayor-officialsquit.html );

"University of Oklahoma frat closed over racist chant". (Retrieved from: http://www.newser.com/story/203733/university-of-oklahoma-frat-closed-over-racist-chant.html); "Soccer fans face prison over racist subway antics" (Retrieved from: https://lockerdome.com/6724405749495105/7429379433170196);

"Racist Graffiti Shuts Connecticut College down" (Retrieved from: http://www.newser.com/story/204726/racist-graffiti-shuts-connecticut-college-down.html)

The following link directs to Fresh Prince of Bel Air episode: https://www.youtube.com/watch?v=p6XVWjorVwA 
transform, discuss and reflect upon relevant topics. They were making a meaningful use of the English, which is, without doubts, a great way to make students realize how important the language can be in their lives. (Excerpt 7 - Kleber's journal)

Furthermore, the students were able to present their arguments in an understandable and compelling manner which was very important in the moment they had to expose their opinions about the situations presented. Considering their posters, their reflections seemed to be everything but shallow. I hope they were touched by the theme as much as I was. (Excerpt 8 - Diego's journal)

Their sense of achievement that can be identified in these excerpts, especially regarding English I students' use of language to produce meaning related to the issues of their interest. By doing so, the grammar points, which were part of the linguistic content to be tackled during the class, turned out to be meaningful. This is also true regarding Isabel's classes since, when she planned them, she tried to match the class theme to the grammar or language content that had to be or that had been taught. This was done not as a 'focus on form' approach, but rather as a 'work with genre' one. However, bearing in mind that texts are made of sentences and words, the first-year students' attention were also directed to the author's word choices and the implications of these choices to meaning making, identity, ideologies, and power relations. Such an approach was used to written as well as to oral texts (such as interviews, faceto-face interaction in TV series and films, and so on). At this point, we would like to emphasize Kleber and Diego's concern regarding their choice for bringing some non-standard or any other variety of English to class ${ }^{11}$ in order to give prominence to different accents and ways of producing meaning in English.

As a matter of fact, before this class, the teaching assistants and Isabel were quite puzzled by the fact that in some of the 'regular' English classes the group did not participate as much as they were expected to do as Diego mentioned in his journal.

One of the puzzles of our small group (Isabel, Kleber and I) seemed to be: why some students of the Inglês I class seemed not to be participative and motivated to talk during the "regular classes" of the course? This puzzle moved us to think about other possibilities in order to make the students more engaged. Personally, I had another puzzle before the class: why some of the classes that I construct seem to be unattractive to some students? However, by the end of the class, another puzzle popped in my mind:

\footnotetext{
${ }^{11}$ As a matter of fact, they had been encouraged to use oral and written manifestations of English used by speakers of different parts of the world. Later, they produced another activity that focused on women's condition in India, due to recent raping reports in the media. The following link directs to the video used for the listening activity https://www.youtube.com/watch?v=8hC0Ng_ajpY
} 
why the majority of the students, including those that usually do not seem to be engaged, felt more willing to participate of the discussions? (Excerpt 9 - Diego's journal)

Through his words, it can be seen that there were different puzzles at play ranging from group to personal ones. Regarding Diego's own puzzles, he started with one that focused on a negative issue ("why some of the classes that I construct seem to be unattractive to some students?") and, after the class, it turned out to be a positive one ("why the majority of the students, including those that usually do not seem to be engaged, felt more willing to participate of the discussions?'). Possibly the students felt so comfortable in that context that participating was not a burden. At this time we want to make a link with Kleber's thoughtfulness regarding the construction of an emotional "safe environment" for these colleagues - as he expressed in excerpt 1 - in order to encourage their participation.

Surely, the way the PEPA was implemented required the use of different genres in the sense brought by the Academic Literacies approach (LEA \& STREET, 1998) - private thinking, group discussion, note taking, poster production, and oral presentation. Isabel's concern in the English classes was also geared towards promoting the creation of a supportive atmosphere through the teaching-learning activities so to encourage participation and possibly enhance learning opportunities. In this way, she could realize that the students usually felt more comfortable whenever the classes at college resembled classes at language courses, which are the privileged site for English learning prior to college entrance in Brazil. At same time, considering Lea and Street's discussion on the Academic Literacies approach, maybe there could be a move on the teacher's (Isabel's) side in order to analyze how the written texts (as well as oral presentations) she asked her students to produce involved the development of some awareness on academic literacies the students would need in other courses related to English at college (such as English II, III and so on; American and British literature; English Language Methodology). In other words, besides hosting the literacies that English I students brought with them to college, she should extend her concern to reflect on how her approach took into account not only the nature of student writing in her institution, but also, in this case, the nature of oral production required in this context for this is also 
relevant in academic literacy practices of the sort required in this graduation course. She should equally think of these issues with respect to power relations and identities.

Still following the Exploratory Practice approach on encouraging the practitioners to share the outcomes of group discussion, puzzles and/or understandings through poster production, Diego and Kleber included this step in their class, as can be seen in excerpt 10 below.

Finally, in the third part of the class, the students were asked to produce a poster in which they would expose their puzzles carved during the group debate they would have just had. The production of the poster would be a good opportunity for the students to transform their intellectual thought about the theme of racism in a visual material.

Giving the opportunity of all the people involved in the different parts of the class to participate in its construction was the major role played by EP in this specific class. Professor Isabel, Kleber and I played our role in thinking about the topic of the class and designing its raw structure. However, the students also played a crucial role in the class once they were free to come up with their own puzzles. The students had autonomy over their productions. As long as they stuck to the topic presented, they could tilt their reflections towards wherever they wish, being thus responsible for the outcome of the class. Furthermore, the students as teachers "em formação" (sorry but I don't know how to say this expression in English) could have the opportunity to think about the process of construction of the class in which they were playing, at the same time, the role of students and producers of it. (Excerpt 10 - Diego's journal)

We highlight Diego and Kleber's efforts to engage their colleagues in class development, encouraging them to exercise their agency as learners of a foreign language, pursuing not only their communicative objectives, but also their personal/citizen aims in class. Another issue worth highlighting is Diego and Kleber's focus on collaborating in their colleagues' professional education ([they] "could have the opportunity to think about the process of construction of the class in which they were playing, at the same time, the role of students and producers of it." ). Still turning our eyes at the teacher education process under way, we add excerpts 11 and 12 below. They reveal Diego's and Kleber's evaluation regarding the whole process of planning, implementing and analyzing the outcomes of a class that integrated teaching-learning-reflecting within an Exploratory Practice framework.

Concerning my experience, this entire process taught me a lot. First, it was the first time I presented a class to students that are going to be teachers. This pressure was a challenge and also a big motivation for me. Secondly, it was the first time I had the opportunity to construct a class in a group. These different perspectives were the ingredient that allowed this class to be so rich. Finally and maybe the most important, this experience taught me that the students should have their participation in the construction of their class. They should be a pair of building hands rather than a pair of watching eyes. Even though I have read plenty of texts about these ideas during the Course of Letras, 
this class was a real opportunity to learn why it is so important to give autonomy to the students to participate in the design of their own class. By the end of this entire process, I felt like I have learned so much more than "the students". Maybe it might be a good outcome for a class. (Excerpt 11 - Diego's journal)

For me, as student and future professor, this experience carries a lot of significance and foundations to what I call my teaching persona, since was possible to visualize and to put and to practice everything that we had learned and read for the past semesters, filling the gaps between the theory and the practice. (Excerpt 12 - Kleber's journal).

From both excerpts, we notice how the whole process and each part of it promoted meaningful learning opportunities. We highlight, in Diego's evaluation, the recognition that learners are capable of decision making and of acting ("students should have their participation in the construction of their class"). They can be autonomous. Besides, he could link the content of the academic texts he had read to a real class. The same perception was true in relation to Kleber ("since was possible to visualize and to put and to practice everything that we had learned and read for the past semesters"). A possible understanding that could be generated is that theory and practice are inextricably connected. Another highly significant aspect, from the perspective of Exploratory Practice, is that these future teachers are already becoming practitioners as part of their initial teacher education. We can see in their discourse that, within the Exploratory Practice framework (ALLWRIGHT, 2006), they are theorizing about their own pedagogic practice. In so doing, they are becoming agentive producers of knowledge in their own field of professional practice.

\section{2 - The puzzles and the posters}

Now, we will to turn the focus of our attention to the posters produced by English I students out of their group discussion. Although the moments when the students shared their puzzles and the discussion they generated were not audio recorded, the posters were photographed. Below we present the first one. 
The puzzles generated and written by the English I students on the sheets of paper revealed their concern for the racial issue from a more general to a more specific focus. These students had been encouraged to produce 'why' questions in order to avoid turning to 'how' to-questions and trying to seek for solutions before they actually tried to understand the intricacies of such a situation. Considering this, we call attention to Poster 1. It starts with a simple but basic and relevant question/puzzle: 'Why does racism exist?'

As we analyze the second question

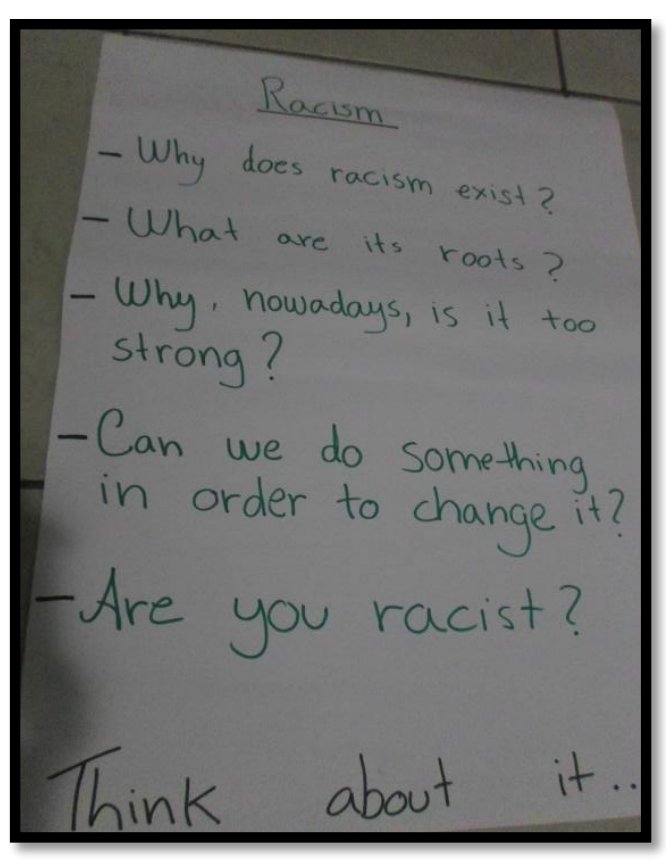

Poster 1

('What are its roots?), it seems that the group was trying to map historical and social motives or explanations for racism, which might have led them to the next one ('Why, nowadays, is it too strong?') possibly linking the flow of ideas to the racist episodes mentioned in the different news reports (see footnote 10 for more information). With the fourth question, these practitioners make their first step from 'working for understanding' to thinking about change. In the sequence, the next question may seem out of a logical order, at first sight. Nevertheless, it is pointing to what should be the starting point for change: each one of us has to honestly understand our position or attitude regarding racism and then individually start acting in ways that can entail social change.

In Poster 2, the practitioners directly relate their first puzzle to the racist event witnessed by Brazilian Facebook users (or even by those from other countries), while the second

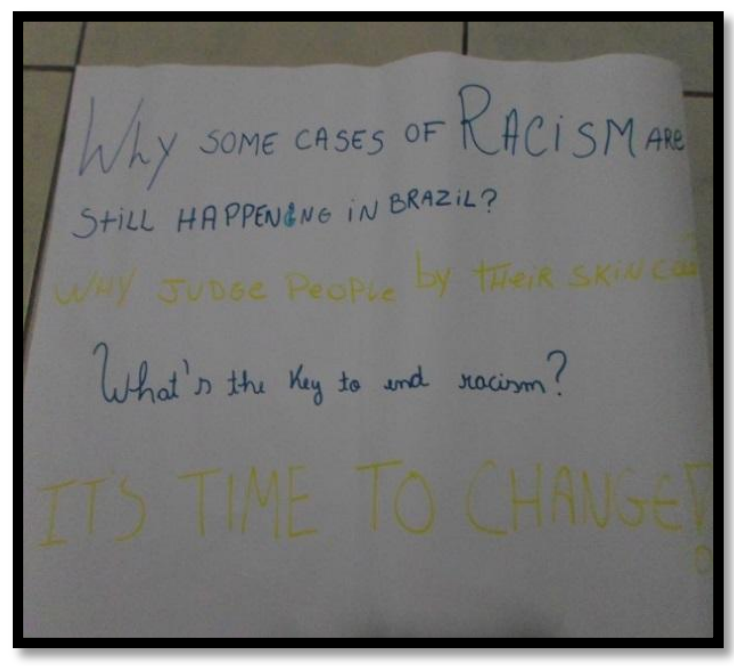

Poster 2 
one may also be linked to the racist events which had happened in the USA (Parma, Missouri; Norman, Oklahoma; New London, Connecticut) and France (Paris).

By addressing real events, especially with the second puzzle, they manage to problematize if the color of a person's skin might be considered an important issue to take into account when one considers a human being instead of this person's attitudes and actions. Indeed, when they mention 'skin color', this may be expanded to any ethnic group, such as Latin Americans, Indians, Asians, including white people who might be stigmatized in other cultural settings. As a matter of fact, during poster presentation, more personal narratives were shared, and the practitioners mentioned how relative the nature of the stigmatizing feature may sometimes be, since, depending on the situation, it can range from skin color to weight, from age to sexual orientation, and even to other aspects.

In the third puzzle ('What's the key to end racism?') again there is a movement towards finding a way out of racism. This movement is reinforced by the last sentence in the poster, which is not a puzzle, but a call for action. We would like to underline how all of these practitioners were tuned to Kleber's and Diego's objectives for the class, namely, to provide an opportunity for their colleagues to improve their use of English in a meaningful situation and to reflect on life outside the language classroom as well as on how life inside the classroom was related to it. Therefore, in spite of using the language in a classroom situation, English I students, as exploratory practitioners, were also using it for reflecting on the social world, and to use this language to produce 'new meanings'.

Poster 3, like Poster 2, presents an even more situated reference to racism in everyday life through word choice and sentence construction. By framing what was going to be addressed in the $21^{\text {st }}$ century, these practitioners involve the readers into reflecting if the puzzles and statements that followed fit the current days, especially the first puzzle that asks why racism is still in the world's social and political agenda. The concern on job opportunities addressed by the second puzzle indirectly includes a reflection on schooling opportunities as well as on the quality of education offered to black students (and we would 
add to poor students too), including the quality of education facilities available to them.

The third ('Why do we still have to deal with racist issues in a multiracial country like Brazil?') and the fourth ('Where are black people in our universities?) puzzles continue narrowing down the reflection focus since it goes from the macro context (Brazil) to the micro one (the universities). In the last sentence, we once again find a call for action ('Join us at UERJ, let's fight together against racism.'). This time, however, the action must be taken inside their own university. We call attention to the use of colors to write puzzles three, four and the last sentence. The students used the same colors of the Brazilian flag - yellow and green - what influenced meaning production.

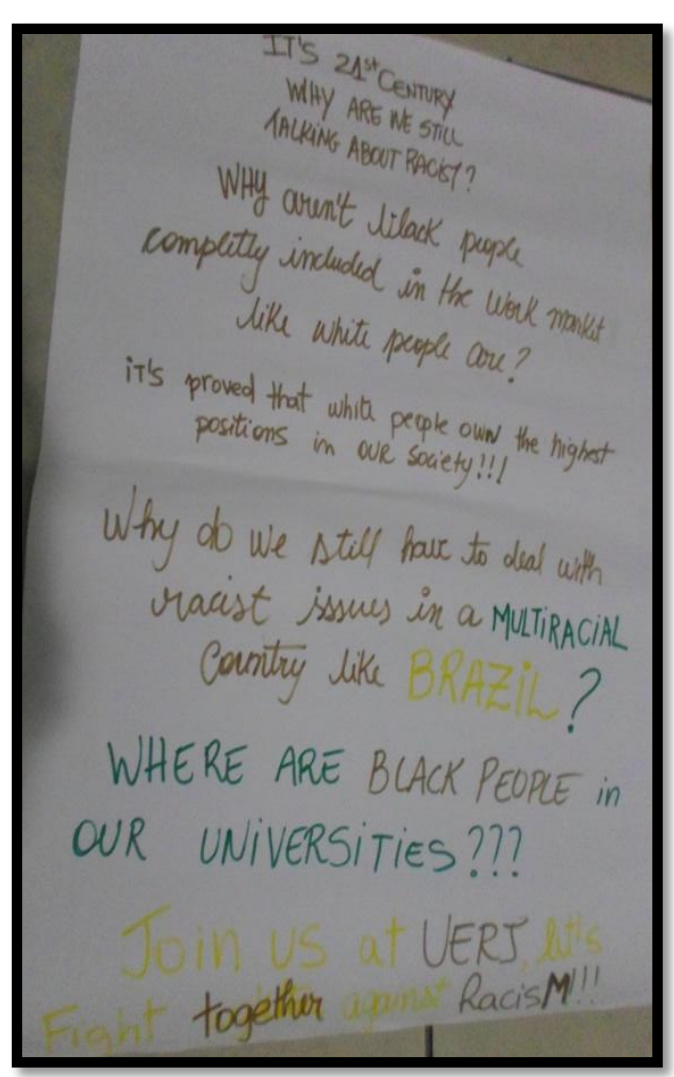

Poster 3

Finally, we present Poster 4. It is relevant to mention that, from the very first group activity, the practitioners who produced this poster called themselves The Niggas. The puzzle that is placed on the central part of the page ('Why so racist?') is surrounded by many 'whys' and curiously by other sentences that despite of being 'why' questions reveal a racist standpoint ('why are you dating a black girl?' or 'why did you invite a nigga to your party?).

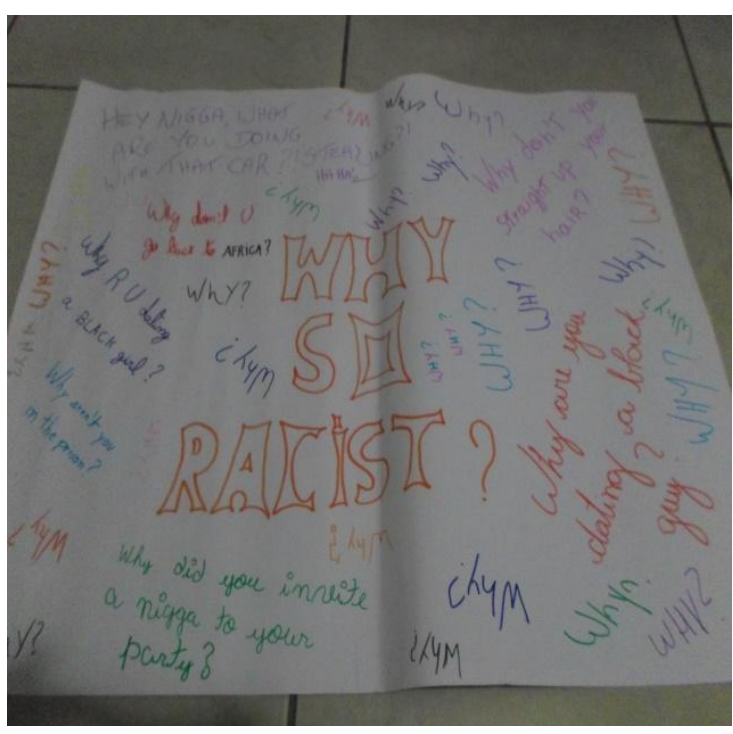

Poster 4

In this case, it seems that they are using questions made by racist people to question these people's discourse and the Discourses on racism. The 
colored sentences and the layout of the poster helped them produce meaning in a creative way.

The manner these practitioners used English to put forth their reflections was validated by their teacher, that is to say, she accredited the linguistic knowledge they brought to college. These points to some positive aspects. One of them regards a fact related to learning and development to which Vygotsky (1986) called attention: the link between thought and affect. Instead of treating thoughts as autonomous entities, Vygotsky claimed that they are closely associated to the fullness of life, as well as to the thinkers' interests, personal needs and inclinations. He also claimed that learning processes are socially, historically, and culturally situated, and that language plays a central role in them. The same is true regarding mind development. According to this line of thought, affect is also situated and language has a role to play in relation to how affect is generated in human encounters. Thus, the encouragement to speak and write and the hosting of the students' contribution to reflection as a valid one in this situated experience might have facilitated their engagement in class.

Vygotsky did not mention power relations among participants of a situated teaching-learning experience in his theory, but we believe that issues of this sort can be added. So, in a Goffmanian sense, and thinking about the here and now of a situation, the power relations present in any interaction, although this situation might have the macro social organization framing how participants act, what they say, and the status they have, it is also negotiated and designed locally. Thus, the way these participants place themselves and the others in the face-to-face interaction might produce an encounter in which the asymmetric relations turn into more symmetric ones. In this experience, the evident asymmetry among participants was reduced as the activity was developed and they negotiated their ideas through the use of language - English and sometimes Portuguese - foregrounding their personal narratives.

This discursive movement and action lead to issues of identity construction (HALL [1992] 2011; WOODWARD, [2000]2003; MOITA LOPES, 2002, 2006) since

discourse has a constitutive nature in the sense that, when we are engaged in discourse, besides representing the world, we are also constructing the discursive practices in which we act [...]. This view also implies that when we use language we are in fact acting in the 
world, doing things to each other through the meanings we construct. (MOITA LOPES, 2006, p. 292)

Thus, through questioning discourses of racial prejudice, through reading the news reports and discussing the racist events recounted, through sharing their personal narratives and thinking about life in and out of college, power relations, and so on, the students and the teacher were involved in a process of identity [re]construction.

Again, the literacies the English I students had brought to their English I classes at college were acknowledged and validated by the teacher. However, as Lea and Street (2010) assert academic practices take place in institutions that are the locales of discourse and power. Moreover, it cannot be ignored that there are literacy demands of the curriculum that should be accounted for. These students should not keep to the literacies that they already knew and that were already part of their linguistic repertoire. At college, other literacies and linguistic repertoires appropriate to each setting would be required. Therefore, these students needed to learn them and use them for their own concerns, bearing in mind that they would also have to handle the social meanings and identities evoked by each of these repertoires, which might convey affective and ideological conflicts as already emphasized by Lea and Street (2010).

\section{4 - Exploratory Practice and New Literacy Studies: a possible dialogue?}

As promised at the beginning of this text, we first presented the main ideas that characterize Exploratory Practice and the New Literacy Studies, areas between which we intend to establish explicit connections. Based on the exploratory teaching assistants' detailed reflexive journals, we narrated and discussed an Exploratory Practice experience that was carried out in a Teacher Education College in the state of Rio de Janeiro. Our intention now is to thematize and interweave, in the light of the New Literacy Studies, the practitioners' perceptions with the situated literacy practices that emerged in the Exploratory Practice process.

The most encompassing aspect is the social orientation to foreign language education and to literacy development in an initial teacher education 
context. The teaching assistants' written records of their planning and reflective follow-up of their classroom practices suggest a social view of pedagogy that interconnects issues in the macro social context with the micro social interpersonal relations that are built among individuals in the group. A constant understanding of the situatedness of social practices appears to inform the planning of rich opportunities for language teaching and learning, for developing understandings, and for literacy and genre awareness-raising. Exploratory Practice is principled and respects idiosyncrasies, just as the New Literacy Studies assume that literacy practices are culturally sensitive and vary from one context to another.

Moreover, the Exploratory Practice experience we brought to focus - in fact any classroom experience framed by Exploratory Practice and made real in other practitioners' classrooms so far - carries the potential of having different literacies at play and hybrid literacies as outcomes. Even at college - as the experience shared in this study - the academic literacies and linguistic repertoires required will not be developed through an essentialized process. These literacies and repertoires will necessarily meet and blend with the ones brought to the university by undergraduate students.

The concern with 'quality of classroom life' does not mean proposing of a set of actions in order to achieve quality in a technicist view. Understanding is prioritized. Exploratory Practice addresses the 'quality of life' issue from the practitioners' stand point - the emic orientation - and it is related to how they perceive the interpersonal relations that construct the classroom affective and social atmosphere; thus, influencing people's relationships throughout the teaching-learning process. We understand that the concern voiced by Lea and Street regarding the affective and ideological conflicts provoked by switching linguistic repertoires, which may be lived by students, bear a relation to 'quality of life' as addressed by Exploratory Practice. We assume that both traditions have a concern towards the other - in a Bakhtinian sense - in the everydayness of a learning community.

Consequently, holding on to the emic perspective is also a strong emerging connection between the exploratory and the literacy practices illustrated. The insiders' beliefs, feelings, perceptions and agencies are recurrently referred to as central to the unfolding process. Such principled and 
mutual care with those involved nurtures the group's quality of life. The teaching assistants, who are also cared for by their teacher educator, carefully plan their lessons bearing in mind their learners' human involvement and well-being in the learning process and in the classroom context. Diversity and autonomy within the group are also ethically sought after, inasmuch as teaching assistants and their learners alike are encouraged to find opportunities in which to express their own thinking in a supportive environment.

Finally, we are becoming confident that by introducing Exploratory Practice and New Literacy Studies at this point in undergraduate students' lives, we may be contributing quite strongly not only to their future professional lives but especially to their self-esteem as human beings.

\section{References}

ALLWRIGHT, D. Observation in the language classroom. London: Longman, 1988.

. Social and pedagogical pressures in the language classroom: The role of socialization. In: H. COLEMAN (Ed.) Society and the language classroom. Cambridge: Cambridge University Press, 1996.

Contextual factors in classroom language learning: An overview. In: MALMAKJER, K.; WILLIAMS, J. (Eds.), Context in language learning and language understanding. Cambridge: Cambridge University Press, 1998.

Three major processes of teacher development and the appropriate design criteria for developing and using them. In: JOHNSTON, B.; IRUJO, S. (Eds.). Research and practice in language teacher education: Voices from the field. Minneapolis, MN: Center for Advanced Research on Language Acquisition, 2001.

Exploratory Practice: Rethinking practitioner research in language teaching. In: ROD, E. (Ed.) Language Teaching Research Journal. London: Arnold, v.7, n. 2, 2003a.

Planning for understanding: A new approach to the problem of method. Pesquisas em Discurso Pedagógico: Vivenciando a Escola. Rio de Janeiro: PUC-Rio, v. 2, n. 1, 2003b. 
Six promising directions for Applied Linguistics. In: GIEVE, S.; MILLER, I.K. (Eds.). Understanding the language classroom. Hampshire, UK: Palgrave Macmillan, p. 11-17, 2006.

Prioritizing the human quality of life in the language classroom: Is it asking too much of beginning teachers? In: GIL, G.; VIEIRA-ABRAHÃO, M.H. (Eds.). A formação do professor de línguas: Os desafios do formador. Campinas, SP: Pontes, 2008.

Inclusive practitioner research: why we need it and what exploratory practice offers. In: YOSHIDA, T. et al. (Orgs.) Researching language teaching and learning: an integration of practice and theory. Oxford: Peter Lang, 2009.

ALLWRIGHT, D.; BAILEY, K.M. Focus on the language classroom: An introduction to classroom research for language teachers. Cambridge, UK: Cambridge University Press, 1991.

ALLWRIGHT, D.; HANKS, J. The developing language learner: An introduction to exploratory practice. Basingstoke, UK: Palgrave Macmillan, 2009.

ALLWRIGHT, D.; MILLER, I. K. Burnout and the Beginning Teacher. In: Soneson, D. and Tarone, E., CHAMOT, A.U.; MAHAJAN, A.; MALONE, M. (Eds.). Expanding our horizons: Language teacher education in the 21st century. Minneapolis: Center for Advanced Research on Language Acquisition (CARLA), 2012.

BAKHTIN, M. Estética da criação verbal. São Paulo: Martins Fontes, [1992]2000.

BARTON, D.; HAMILTON, M.; IVANIC, R. Situated Literacies. London: Routledge, 2000.

BARRETO, de C. B.; REIS, B. de M.; MILLER, I. K.; MONTEIRO, M. de G.; CUNHA, M. I. A.; MOURA, S. M. L. Atividades com Potencial Exploratório: Caminhos para a coconstrução de entendimentos. Forthcoming.

BRASIL. Parâmetros Curriculares Nacionais: terceiro e quarto ciclos do ensino fundamental - Língua Estrangeira. Brasília: Ministério da Educação e Cultura, Secretaria de Ensino Fundamental, 1998. 
Orientações Curriculares para o Ensino Médio. Linguagens, Códigos e suas Tecnologias. Brasília: Ministério da Educação e Cultura, Secretaria de Educação Básica, 2008.

CAZDEN, C. Classroom discourse: the language of teaching and learning. Portsmouth: Heinemann, 1988.

ERICKSON, F. Ethnographic Microanalysis. In: McKay, S.L.; N.H. HORNBERGER (Eds.) Sociolinguistics and language teaching. Cambridge: Cambridge University Press, 1996.

EWALD, C. "Eu não tô só participando. Eu tô usufruindo também." Prática Exploratória na formação do professor pesquisador. Tese de Doutorado. Pós-Graduação Stricto Sensu. Departamento de Letras. PUC-Rio, 2015.

GEE, J. P. The New Literacy Studies - From 'socially situated' to the work of the social. In: BARTON, D.; HAMILTON, M.; IVANIC, R. (ed.) Situated Literacies - Reading and writing in context. London, New York: Routledge, 2000.

\section{A Situated Sociocultural Approach to Literacy and Technology.}

N.d. Retrieved from: http://www.csun.edu/sites/default/files/James-Geesociotech.pdf

GIEVE, S.; Miller, I.K. What do we mean by 'Quality of Classroom Life'? In: GIEVE, S.; Miller, I.K. (ed.) Understanding the Language Classroom. Hampshire, New York: Palgrave MacMillan, 2006.

HALL, S. A identidade cultural na pós-modernidade. Rio de Janeiro: DP\&A, [1992]2011.

HAMILTON, M. The social context of literacy. In: HUGHES, N. Teaching Adult Literacy. Berkshires, Glasgow: Open University Press, McGraw-Hill House, 2010.

HEATH, S.B. Protean shapes in literacy events: Ever shifting oral and literate traditions. In: TANNEN, D. (Ed.) Spoken and written language: Exploring orality and literacy. Norwood: Ablex, 1982.

HOLLIDAY, A. Small Cultures. Applied Linguistics. 20/2, 1999237-264.

LEA, M.; STREET, B.V. Student Writing in Higher Education: an Academic Literacies Approach. Studies in Higher Education. Jun., vol. 23, Issue 2, 
1998.

Retrieved

from:

https://www.kent.ac.uk/teaching/documents/qualifications/studwritinginhe.pdf

into Practice. 45 (4), 2006. Retrieved from: http://www.researchgate.net/publication/47343136_The_academic_literacies_m odel_Theory_and_application

MILLER, I. 'Puzzle-driven' language teacher development: the contribution of Exploratory Practice. In: Yoshida, T. et al. (Orgs.). Researching language teaching and learning: an integration of practice and theory. Oxford: Peter Lang, 2009.

Construindo parcerias universidade-escola: caminhos éticos e questões crítico-reflexivas. In: Gimenez, Telma; Góes, Maria Cristina G. (Orgs.). Formação de professores de línguas na América latina e transformação social. Campinas, SP: Pontes Editores, 2010.

A prática exploratória na educação de professores de línguas: inserções acadêmicas e teorizações híbridas. In: Silva, Kleber; Daniel, Fátima G.; Kaneko-Marques, Sandra M.; Salomão, Ana Cristina B. (Orgs.). A formação de professores de línguas: Novos olhares - Volume II. Campinas, SP: Pontes Editores, 2013.

MILLER, I. K.; BARRETO, B. C.; MORAES BEZERRA, I.C.R.; CUNHA, M. I. A.; BRAGA, W. G.; KUSCHNIR, A. N.; SETTE, M. de L. Prática exploratória: questões e desafios. In: GIL, G.; VIEIRA-ABRAHÃO, M. H. (Eds.). A formação do professor de línguas: Os desafios do formador. Campinas, SP: Pontes, 2008 a.

MILLER, I. K.; BARRETO, B. C.; MONTEIRO, M. C. de G. O Entrelugar do Estágio: Oportunidades para Entender. Pôster apresentado no II Congresso Latino-Americano de Formação de Professores de Línguas, Rio de Janeiro. Caderno de Resumos. Rio de Janeiro: Edições Entrelugar, v. 1. 2008 b.

MILLER, I. K.; CUNHA, M. I. A.; Members of the Rio de Janeiro EP group. The 'web of life' of the Rio de Janeiro Exploratory Practice group. In: ALLWRIGHT, D.; HANKS, J. The developing language learner: an introduction to Exploratory Practice. Hampshire, UK: Palgrave Macmillan. 2009.

MILLER, I.K., CÔRTES, T.C.R., OLIVEIRA, A.F.A., BRAGA, W.G. Exploratory practice in initial teacher education: Working collaboratively for understandings. In Bullock, D.; Smith, R. Teachers Research! Forthcoming. Faversham: IATEFL. 2015. 
MOITA LOPES, L.P. Identidades fragmentadas: a construção discursiva de raça, gênero e sexualidade em sala de aula. Campinas: Mercado de Letras, 2002.

. On being white, heterosexual and male in a Brazilian school: multiple positionings in oral narratives. In: DE FINA, A.; SCHIFFRIN, D.; BAMBERG, M. (ed.) Discourse and Identity. Cambridge: Cambridge University Press, 2006.

MORAES BEZERRA, I.C.R. "Com quantos fios se tece uma reflexão?" Narrativas e argumentações no tear da interação. Tese de Doutorado. Rio de Janeiro: Departamento de Letras, PUC-Rio, 2007.

. Prática Exploratória, espaços formativos e a educação crítica de professores de inglês: o olhar híbrido de uma professora formadora. Revista X. vol.2, $2011 . \quad$ Retrieved from: http://ojs.c3sl.ufpr.br/ojs/index.php/revistax/article/viewFile/23015/17914

. Prática Exploratória e a formação inicial do Professor reflexivo: "o que vai ficar para os alunos? Revista Contemporânea de Educação. vol. 7, n. 3, 2012.

. Desafios na formação do professor de inglês: discurso, contexto sóciohistórico, prática e reflexão. Pensares em Revista. n. 4, 2014. Retrieved from: http://www.e-

publicacoes.uerj.br/index.php/pensaresemrevista/article/view/14119

- Gêneros discursivos, ensino de língua estrangeira e prática docente: a vida em capas de revistas. In: WILSON, V.; MORAIS, J. de F. dos S. Leitura, escrita e ensino: discutindo a formação de leitores. São Paulo: Summus Editorial, 2015.

SLIMANI, A. The teaching/learning relationship: Learning opportunities and the problems of uptake - an Algerian case study. Unpublished Doctoral Dissertation. Linguistics Department. Lancaster University. 1987.

STREET, B. Social Literacies: critical approaches to literacy in development, ethnography and education. London: Longman, 1995.

Autonomous and Ideological Models of Literacy: approaches from New Literacy Studies. N.d. Retrieved from: http://www.philbu.net/mediaanthropology/street_newliteracy.pdf 
What's "new" in New Literacy Studies? Critical Approaches to literacy in theory and practice. Current Issues in Comparative Education. Teachers College, Columbia University. Vol.5(2), 2003. Retrieved from: http://people.ufpr.br/ clarissa/pdfs/NewlnLiteracy_Street.pdf

Recent Applications of new Literacy Studies in Educational Contexts. Research in the Teaching of English. The National Council of Teachers of English. Vol. 39, n. 4, 2005.

"Academic Literacies approaches to genre?" Revista Brasileira de Linguística Aplicada. Vol. 10, n. 2, Belo Horizonte, 2010. Retrieved from: http://www.scielo.br/scielo.php?pid=S1984-

63982010000200004\&script=sci_arttext

SANTOS, M.R.F. B. Why do my adult students have difficulties with listening activities? - An Exploratory Case Study. Monografia PósGraduação Lato Sensu. Departamento de Letras. PUC-Rio. 2015.

VYGOTSKY, L. S. Thought and Language. Cambridge, Massachusetts: The MIT Press, 1986.

WENGER, E. Communities of Practice - Learning, meaning and identity. New York: Cambridge University Press, 1998.

WOODWARD, K. Identidade e diferença: uma introdução teórica e conceitual. In: SILVA, T.T. (org.) Identidade e diferença: a perspectiva dos Estudos Culturais. Rio de Janeiro: Vozes, [2000]2003. 
Artigo recebido em: 20 de julho de 2015

Artigo aprovado em: 20 de setembro de 2015

\section{About the authors:}

Isabel Cristina Rangel Moraes Bezerra is member of the Exploratory Practice Group in Rio de Janeiro (PUC-Rio) and member of the research group Language and Society (UERJ/FFP-CNPq). Universidade do Estado do Rio de Janeiro (State University of Rio de Janeiro).

Inés Kayon de Miller is mentor of the Exploratory Practice Group in Rio de Janeiro (PUC-Rio). Pontifícia Universidade Católica do Rio de Janeiro (Pontifical Catholic University of Rio de Janeiro). 